\title{
AMERICA'S BATTLE FOR MEDIA DEMOCRACY: THE TRIUMPH OF CORPORATE LIBERTARIANISM AND THE FUTURE OF MEDIA REFORM
}

\author{
GUEST SPEAKER: \\ VICTOR PICKARD \\ ASSISTANT PROFESSOR \\ ANNENBERG SCHOOL FOR COMMUNICATION \\ UNIVERSITY OF PENNSYLVANIA \\ TUES. APRIL 7 ${ }^{\mathrm{TH}}$, 3:00 - 5:00 P.M. \\ SIMON FRASER UNIVERSITY, HARBOUR CENTRE ROOM 2270
}
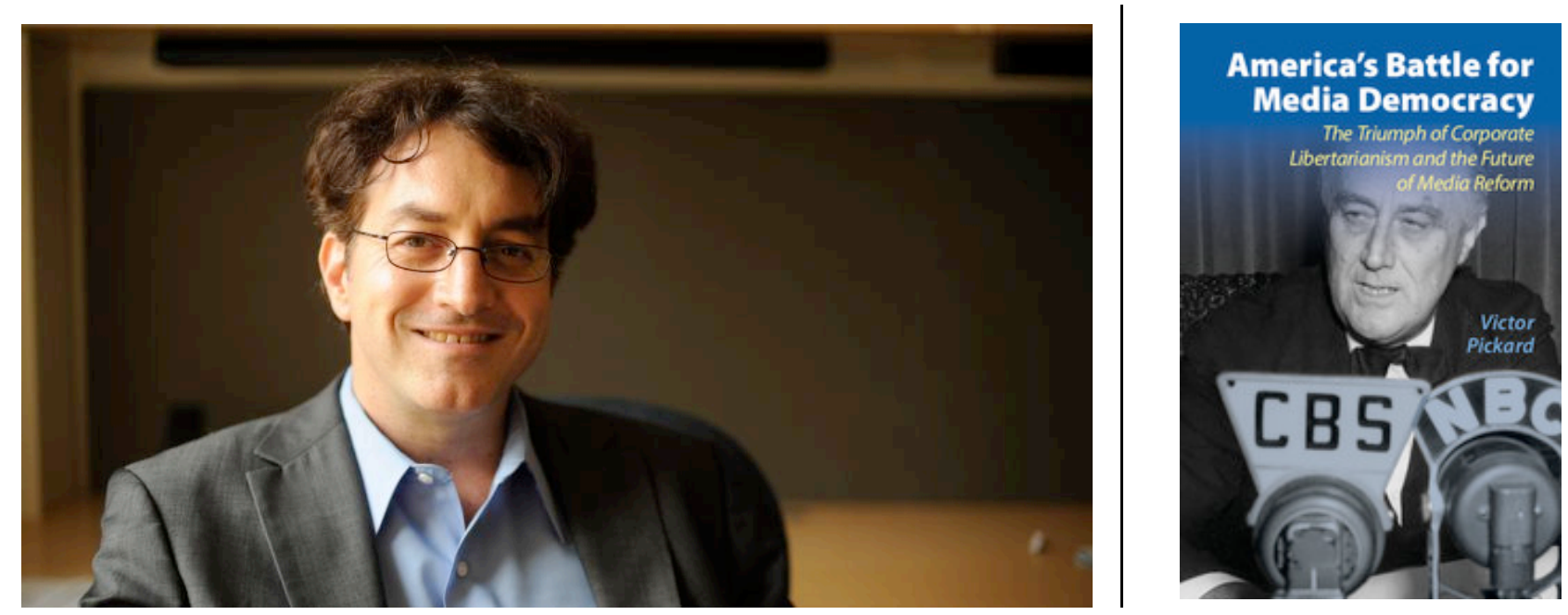

Victor Pickard is an Assistant Professor at the Annenberg School for Communication at the University of Pennsylvania. Previously he taught media studies at NYU and the University of Virginia, and he worked on media policy at various institutions in Washington, DC. He served as a Senior Research Fellow at Free Press and the New America Foundation, and as a Policy Fellow for Congresswoman Diane Watson. He has published over 50 scholarly articles and book chapters on the history and political economy of media institutions and media activism. He frequently speaks to the press about current policy debates and his op-eds have appeared in news outlets like The Guardian, The Huffington Post, and The Atlantic. He is the editor (with Robert McChesney) of Will the Last Reporter Please Turn Out the Lights and the author of America's Battle for Media Democracy.

\author{
CO-SPONSORS: \\ * School of Communication, SFU \\ * Faculty of Communication, Art \& Technology, SFU \\ * Institute for the Humanities, SFU \\ * Labour Studies Program, SFU \\ * mediademocracyproject.ca
}

All members of SFU and the public are invited to this special session of CMNS 840 (Political Economy of Communication). For further information, and to RSVP, please contact Prof. Bob Hackett 